\title{
Karakteristik Kimia dan Organoleptik Snack Bar Biji Hanjeli (Coix lacryma jobi- $L$ ) dan Kacang Bogor (Vigna subterranea (L.) Verdcourt)
}

\section{Chemical and Organoleptic Properties of Snack Bar Hanjeli Seeds (Coix lacryma jobi-L) and Bogor Beans (Vigna subterranea (L.) Verdcourt)}

\author{
Siti Aminah1a, Lia Amalia1, Siti Hardianti1 \\ ${ }^{1}$ Jurusan Teknologi Pangan dan Gizi, Fakultas Ilmu Pangan Halal, Universitas Djuanda Bogor \\ Jl. Tol Ciawi No.1, Kotak Pos 16720. \\ aKorespondensi: Siti Aminah, E-mail: siti_aminah@unida.ac.id
}

(Diterima oleh Dewan Redaksi: 20 - 09 - 2019)

(Dipublikasikan oleh Dewan Redaksi: 30 - 10 - 2019)

\begin{abstract}
Hanjeli seeds are a local food of West Java which is still very limited in its processing. So, it is with Bogor beans. Therefore, this study aims to develop local food ingredients of hanjeli seeds and Bogor beans into snack bars. Binders used are chocolate bars and cocoa butter. The treatment given in this study was the comparison of hanjeli seeds and Bogor beans A1 (50:50), A2 (60:40), A3 (70:30). The results obtained from the proximate analysis were snack bar water content ranged from 2.13 to $2.63 \%$. Ash content ranged from 2.27 to $2.60 \%$. Protein water content ranges from 15.19-17.61\%. Fat content ranges between 28, 19$34.46 \%$. Carbohydrate levels ranged from 43.11 to $51.89 \%$. The comparison treatment of hanjeli seeds and bogor beans has no significant effect on water content, but has a significant effect on ash content, protein content, fat content, and carbohydrate content. The hedonic quality test results obtained snack bar has the characteristics of shiny brown color, dark chocolate aroma, sweet taste, and harsh texture. The snack bar energy content ranges from 523.30 to $552.71 \mathrm{Kcal} / 100$ gram of material.
\end{abstract}

Keywords : hanjeli seeds, bogor beans, snack bar.

\begin{abstract}
ABSTRAK
Biji hanjeli merupakan pangan lokal Jawa Barat yang masih sangat terbatas pengolahannya. Begitu halnya dengan kacang bogor. Oleh karena itu, penelitian ini bertujuan untuk mengembangkan bahan pangan lokal biji hanjeli dan kacang bogor menjadi snack bar. Binder yang digunakan ialah cokelat batang dan cocoa butter. Perlakuan yang diberikan pada penelitian ini adalah perbandingan biji hanjeli dan kacang bogor A1 (50:50), A2 (60:40), A3 (70:30). Hasil yang diperoleh dari analisis proksimat adalah kadar air snack bar berkisar antara 2,13-2,63\%. Kadar abu berkisar antara 2,27-2,60\%. Kadar air protein berkisar antara 15,19-17,61\%. Kadar lemak berkisar antara 28, 19-34,46\%. Kadar karbohidrat berkisar antara 43,11-51,89\%. Perlakuan perbandingan biji hanjeli dan kacang bogor tidak berpengaruh nyata terhadap kadar air, akan tetapi berpengaruh nyata pada kadar abu, kadar protein, kadar lemak, dan kadar karbohidrat. Hasil uji mutu hedonik diperoleh hasil snack bar memiliki karakteristik warna cokelat mengkilap, aroma cokelat pekat, rasa manis, dan tekstur yang keras. Kandungan energi snack bar berkisar antara 523,30-552,71 Kkal/100 gram bahan.
\end{abstract}

Kata kunci: biji hanjeli, kacang bogor, snack bar.

Aminah, Siti, Lia Amalia, Siti Hardianti. 2019. Karakteristik Fisikokimia dan Organoleptik Biji Hanjeli (Coia lacryma jobi-L) dan Kacang Bogor (Vigna subterranea (l.) Verdcourt). Jurnal Agroindustri Halal 5(2):212-219 


\section{PENDAHULUAN}

Pangan lokal dapat didefinisikan sebagai pangan yang dihasilkan dan dikembangkan di suatu wilayah tertentu (Utami dan Sulistyani 2015). Salah satu bahan pangan lokal Jawa Barat yang berpotensi untuk dikembangkan adalah biji hanjeli. Berdasarkan Nurmala (2010) biji hanjeli rata-rata mengandung kadar air 11,04\%; kadar karbohidrat 71,81\%; kadar protein 10,89\%; kadar abu 1,38\%; dan kadar lemak 5,18\%. Hal ini menunjukkan bahwa biji hanjeli dilihat dari kandungan nutrisi memiliki potensi yang tinggi untuk dijadikan sumber bahan pangan. Akan tetapi, saat ini bahan pangan tersebut ditanam oleh penduduk secara konvensional kabupaten Bandung, Sumedang, Ciamis, Garut, Sukabumi, Cirebon dan Indramayu (Nurmala 2010). Pengolahan hanjeli sebagai produk pangan masih sangat terbatas, biasanya warga setempat hanya memanfaatkan hanjeli sebagai pangan lokal subtitusi biji pada musim paceklik. Oleh karena itu, sangat diperlukannya inovasi dalam pengolahan biji hanjeli. Salah satu caranya ialah dengan pembuatan snack bar biji hanjeli. Snack bar dikenal sebagai bentuk olahan pangan yang praktis dikonsumsi dan didistribusi serta memiliki umur simpan yang cukup panjang.

Snack bar adalah salah satu jenis olahan pangan yang memiliki karakteristik yang padat dan terbuat dari kombinasi beberapa bahan pangan yang digabung menjadi satu dengan bantuan binder. Keunggulan snack bar di antaranya umur simpan yang Panjang, mengandung kalori yang tinggi, serta tidak mudah rusak dalam pendistribusian (Seismono dan Nikmatul 2011). Pembuatan snack bar dapat dikombinasikan dari beberapa bahan seperti sereal, kacang-kacangan, sayuran, atau buahbuahan bernutrisi (Ladamay dan Yuuwon 2014). Sedangkan binder dalam bar dapat berupa sirup, caramel, coklat, dan lain-lain (Rinda et al. 2018).

Pemilihan bahan pembuatan snack bar dari kombinasi bahan lokal yang memiliki nutrisi yang baik merupakan pilihan yang tepat. Snack bar dengan komposisi gizi yang cukup dapat menjadi salah satu pilihan pangan sehat (Yan et al. 2017). Salah satunya ialah pembuatan snack bar dengan mengkombinasikan biji hanjeli dan kacang bogor. Kacang bogor merupakan komoditi lokal yang mengandung nutrisi yang tinggi. Kacang bogor memiliki kandungan gizi diantaranya protein sebesar $20,6 \%$, lemak $6,6 \%$, serat $6,3 \%$, abu $3,25 \%$ dan karbohidrat sebesar 56,61\% (Mazahib et al. 2013).. Kacang bogor direkomendasikan menjadi bahan pangan sehat karena memiliki kandungan lemak tak jenuh (palmitat, oleat, linoleat, dan kaprilat) yang sangat penting untuk kesehatan (Adhi dan Sholeh 2018). Di sisi lain, pengolahan kacang bogor masih sangat terbatas. Biasanya kita jumpai kacang bogor hanya dijual dalam bentuk rebusan yang dijajakan di pinggir jalan kota Bogor, atau dalam bentuk kacang bogor goreng yang tersedia di sentra oleh oleh. Oleh karena itu, potensi untuk pengembangan kacang bogor masih terbuka lebar (Pahane et al. 2017).

Berdasarkan kajian di atas, dirasa sangat perlu sebuah inovasi pengembangan bahan pangan lokal khususnya biji hanjeli dan kacang bogor menjadi produk olahan yang praktis dan banyak disukai. Snack bar dipilih agar bahan pangan lokal tersebut lebih dikenal dan mudah dikonsumsi masyarakat.

\section{MATERI DAN METODE}

\section{Bahan dan Alat}

Bahan utama dalam penelitian ini adalah biji hanjeli yang didapat dari petani di Bandung, kacang bogor yang didapat dari pasar bogor, cokelat batang, cocoa butter, dan soda kue.

Alat-alat yang digunakan ialah kompor gas, panci, pisau, Loyang, talenan, refrigerator, timbangan, pisau, baskom, saringan, penggorengan, serta alat-alat untuk analisis proksimat.

\section{Tahapan Penelitian}

Penelitian ini terdiri atas 3 tahapan, yaitu 1) pembuatan puffing hanjeli, kacang 
bogor crispy, dan binder snack bar, 2) pembuatan snack bar, 3) analisis proksimat snack bar meliputi analisis kadar air, kadar abu, kadar protein, kadar lemak dan kadar karbohidrat. Analisis organoleptik snack bar serta perhitungan kandungan energi snack bar biji hanjeli dan kacang bogor.

\section{Pembuatan Puffing, Kacang Bogor Crispy,dan Binder Snack Bar.}

a. Puffing biji hanjeli

Biji hanjeli yang digunakan untuk pembuatan puffing biji hanjeli didapatkan dari seorang owner hanjeli di Kota Bandung. Langkah pembuatan puffing hanjeli terdiri dari beberapa tahap, yaitu pertama biji hanjeli disortasi, dipisahkan dari material asing. Hasil sortasi dilakukan pencucian dengan air mengalir, setelah dilakukan proses pencucian kemudian dilakukan proses perendaman dengan larutan $\mathrm{NaHCO}_{3}$ 5g/1L dengan waktu 1 jam. Selanjutnya, dilakukan penirisan kemudian penggorengan dengan $750 \mathrm{~mL}$ minyak goreng dan suhu $175-200^{\circ} \mathrm{C}$ selama 30 detik. Biji hanjeli yang telah digoreng kemudian ditiriskan.

b. Pembuatan Kacang bogor Crispy

Kacang bogor yang digunakan dalam pembuatan kacang bogor Crispy ini didapatkan dari penjual kacang bogor di pasar bogor. Proses pembuatan kacang bogor Crispy yaitu, pertama kacang bogor disortasi, dipisahkan dari material asing dan kacang bogor yang rusak. Kemudian dilakukan pengupasan kulit dan diteruskan dengan pencucian dengan air mengalir. Selanjutnya dilakukan penggorengan dengan minyak goreng $750 \mathrm{~mL}$ dengan suhu $175-200^{\circ} \mathrm{C}$ selama 30 detik serta dilakukan penirisan.

c. Pembuatan Binder Snack Bar

Pembuatan binder yang digunakan dalam pembuatan snack bar adalah cokelat yang dilelehkan. Proses pembuatan binder, pertama ditimbang cokelat batang $200 \mathrm{~g}$ kemudian dilelehkan dengan suhu $45^{\circ} \mathrm{C}$ dengan waktu 20 menit, pada saat pelelehan cokelat ditambahkan cocoa butter $10 \mathrm{~g}$ dan 20g diaduk sampai homogen.

\section{Pembuatan Snack Bar}

Tahap ini bertujuan untuk menentukan formulasi yang tepat yang mampu menghasilkan produk snack bar dari biji hanjeli dan kacang bogor yang memiliki nilai gizi dan mutu sensori aroma, tekstur, warna dan rasa yang terbaik serta dapat diterima oleh konsumen dengan perlakuan perbandingan biji hanjeli dan kacang bogor A1, A2, A3 (50:50, $60: 40,70: 30)$.

\section{Analisis proksimat, organoleptik, dan kandungan energi snack bar}

Tahap ini dilakukan dengan pengujian sensori snack bar dengan uji mutu hedonik dan uji hedonik dengan skala garis $(0-10 \mathrm{~cm})$ dengan menggunakan parameter warna, aroma, rasa, tekstur. Selain itu, juga dilakukan uji kimia berupa proksimat untuk mengetahui kandungan gizi produk setiap formula dan nilai energi. Uji proksimat dilakukan dengan menganalisis kadar air, kadar abu, kadar protein, kadar lemak, dan kadar karbohidrat by difference (AOAC 1995). Perhitungan kandungan energi mengacu pada Almatsier (2009).

\section{Analisis Data}

Analisis data pada penelitian ini menggunakan program Statistical Product and Service Solution 16.0 (SPSS 16.0) dengan uji statistik yaitu uji sidik ragam (ANOVA) untuk mengetahui apakah perlakuan yang digunakan dalam penelitian berpengaruh nyata atau tidak terhadap parameter. Apabila nilai $\mathrm{p}<0,05$ maka perlakuan berpengaruh nyata maka dilanjutkan dengan uji lanjut Duncan pada selang kepercayaan 95\% (taraf $\alpha=0,05$ ) untuk mengetahui perlakuan mana yang berbeda nyata.

\section{HASIL DAN PEMBAHASAN}

\section{Analisis Proksimat}

Analisis proksimat penting dilakukan untuk mengetahui kualitas produk pangan terutama terhadap standar zat makanan yang seharusnya terkandung di dalamnya 
(Wiryawan A, 2012). Hasil analisis kimia disajikan dalam Tabel 1. snack bar biji hanjeli dan kacang bogor

Tabel 1. Karakteristik kimia snack bar biji hanjeli dan kacang bogor

\begin{tabular}{cccccc}
\hline $\begin{array}{l}\text { Perbandingan biji } \\
\text { hanjeli dan kacang } \\
\text { bogor (\%) }\end{array}$ & $\begin{array}{l}\text { Kadar } \\
\text { air }\end{array}$ & $\begin{array}{l}\text { Kadar } \\
\text { abu }\end{array}$ & $\begin{array}{l}\text { Kadar } \\
\text { protein }\end{array}$ & $\begin{array}{l}\text { Kadar } \\
\text { lemak }\end{array}$ & Kadar karbohidrat \\
\hline $50: 50$ (A1) & $2,58^{\mathrm{a}}$ & $2,27^{\mathrm{a}}$ & $17,61^{\mathrm{a}}$ & $34,46^{\mathrm{a}}$ & $43,11^{\mathrm{a}}$ \\
$60: 40(\mathrm{~A} 2)$ & $2,63^{\mathrm{a}}$ & $2,30^{\mathrm{a}}$ & $16,47^{\mathrm{b}}$ & $33,88^{\mathrm{b}}$ & $44,72^{\mathrm{b}}$ \\
$70: 30(\mathrm{~A} 3)$ & $2,13^{\mathrm{a}}$ & $2,60^{\mathrm{b}}$ & $15,19^{\mathrm{c}}$ & $28,19^{\mathrm{c}}$ & $51,89^{\mathrm{c}}$ \\
\hline
\end{tabular}

Keterangan: Notasi huruf yang berbeda menunjukkan berbeda nyata pada $\alpha=0,05$

\section{a. Kadar Air}

Kadar air snack bar biji hanjeli dan kacang bogor dengan perbandingan biji hanjeli dan kacang bogor seperti pada perlakuan A1, A2, dan A3 tidak berpengaruh nyata pada taraf $0,05 \%$. Kadar air snack bar biji hanjeli dan kacang bogor berkisar 2,13\%, $2,58 \%$, dan 2,63\%. Nilai ini terbilang rendah dibandingkan dengan hasil penelitian Atmaka et al. (2013) yaitu sebesar 15,11\%20,91\%. Rinda et al. (2018) menghasilkan snack bar dengan rata-rata kadar air sebesar $17,70 \%$. Kadar air yang rendah diduga karena penggunaan bahan baku berupa biji yang telah dijadikan puffing dan kacang bogor yang telah melalui proses penggorengan sehingga menguragi sejumlah kadar air. Kandungan air dalam bahan pangan dapat mempengaruhi daya tahan bahan pangan terhadap mikroba, sehingga semakin kecil kadar air bahan pangan, maka umur simpan produk tersebut akan semakin Panjang (Amanto et al. 2015).

\section{b. Kadar Abu}

Kandungan abu menggambarkan kandungan mineral dalam suatu bahan (Sarifudin et al. 2015). Snack bar biji hanjeli dan kacang bogor pada perlakuan A3 dengan perbandingan biji hanjeli dan kacang bogor sebesar 70:30 memiliki kadar abu yang paling tinggi dibandingkan perlakuan A1 dan A2. Purwati et al. (2015) menyatakan kadar kalsium pada biji 100gram biji hanjeli sebesar 11 gram. Nilai ini termasuk tinggi, sedangkan kalsium merupakan salah satu mineral yang akan terdeteksi pada analisis kadar abu.

\section{c. Kadar Protein}

Perlakuan perbandingan biji hajeli dan kacang bogor berpengaruh nyata terhadap kadar protein snack bar biji hanjeli dan kacang bogor. Semakin tinggi persentase biji hanjeli pada perlakuan, kadar protein snack bar yang dihasilkan semakin tinggi. Biji hanjeli memiliki kandungan gizi yang baik, salah satunya adalah kandungan protein sebesar $213 \mathrm{mg}$ per 100 gram bahan. Nilai ini bahkan lebih tinggi dari kandungan protein susu sapi sebesar 143mg per 100gram bahan (Purwati et al. 2015). Rahardjo et al. (2019) membuat snack bar dari kombinasi kacang kedelai dan kacang tunggak yang diperkaya biji nangka dan menghasilkan nilai protein per 100gram snack bar yaitu sebesar 17,85\%. Siregar et al. (2017) menyebutkan bahwa kadar protein snack bar komersial berkisar antara 10-15\%, sedangkan snack bar biji hanjeli dan kacang bogor memiliki kadar protein berkisar $15,19 \%, 16,47 \%$, dan $17,61 \%$ sehingga dapat dikatakan snack bar biji hanjeli dan kacang bogor tinggi protein.

\section{d. Kadar Lemak}

Snack bar biji hanjeli dan kacang bogor memiliki nilai kadar lemak berkisar antara 28,19-34,46\%. Kadar lemak ini berbeda nyata pada taraf $0,05 \%$. Semakin tinggi jumlah kacang bogor pada perlakuan, kadar lemak snack bar yang dihasilkan semakin tinggi. Wibowo (2013) melaporkan snack bar dari kacang merah dan apel malang memiliki kadar lemak sebesar 22,8129,66\%. Sedangkan Arwin et al. (2018) menghasilkan snack bar dari tepung beras 
merah dan kacang merah dengan kadar lemak 20,75\%. Kadar lemak yang lebih tinggi ini disebabkan karena penambahan kacang bogor yang memiliki kadar lemak sebesar 6,6\% (Mazahib et al. 2013). Akan tetapi lemak yang terkandung pada kacang bogor merupakan jenis lemak tak jenuh yang tidak membahayakan kesehatan. Lemak merupakan salah satu faktor penting yang harus diperhatikan dalam produksi makanan. Hal ini karena lemak dapat menyebabkan perubahan sifat kea rah yang tidak diinginkan yaitu ketengikan produk (Andriani et al. 2018).

\section{e. Kadar Karbohidrat}

Kadar karbohidrat by different pada ketiga perlakuan berbeda nyata pada taraf $0,05 \%$. Semakin banyak persentase biji hanjeli pada perlakuan dihasilkan snack bar dengan kadar karbohidrat yang lebih tinggi. Hal ini karena biji hanjeli memiliki kandungan karbohidrat yang cukup tinggi. Qosim dan Tati (2011) melaporkan bahwa komposisi karbohidrat pada biji hanjeli sebesar 71,81\%. Hal ini menunjukkan bahwa biji hanjeli dapat dimanfaatkan sebagai sumber bahan pangan, meskipun nilainya masih lebih rendah jika dibandingkan dengan jagung, beras, sorgum, dan barley.

\section{Analisis Organoleptik}

Analisis organoleptik dilakukan untuk mengetahui secara kompleks karakteristik sensori dari suatu produk. Untuk kepentingan pemasaran, analisis ini penting untuk mengetahui tingkat penerimaan konsumen terhadap produk (Munir et al. 2018). Dalam penelitian ini dilakukan dua jenis analisis organoleptik, yaitu uji mutu hedonik untuk mengetahui karaketristik snack bar berdasarkan penilaian panelis dan uji hedonic untuk mengetahui tingkat kesukaan panelis. Berikut adalah pembahasan selengkapnya.

\section{a. Uji Mutu Hedonik}

Analisis organoleptik dilakukan dengan uji mutu hedonik. Uji mutu hedonik dilakukan untuk mengetahui mutu sensori dari produk snack bar biji hanjeli dan kacang bogor dengan parameter mutu warna, aroma, rasa, dan tekstur. Hasil uji mutu hedonik disajikan pada Tabel 2 .

Tabel 2. Hasil uji mutu hedonik

\begin{tabular}{ccccc}
\hline Perlakuan & Warna & Aroma & Rasa & Tekstur \\
$\begin{array}{c}50: 50 \\
\text { (A1) }\end{array}$ & $5.99^{\mathrm{a}}$ & $6.24^{\mathrm{a}}$ & $6.13^{\mathrm{a}}$ & $6.13^{\mathrm{a}}$ \\
$\begin{array}{c}60: 40 \\
\text { (A2) }\end{array}$ & $6.07^{\mathrm{a}}$ & $6.32^{\mathrm{a}}$ & $6.05^{\mathrm{a}}$ & $6.05^{\mathrm{a}}$ \\
$\begin{array}{c}70: 30 \\
\text { (A3) }\end{array}$ & $5.73^{\mathrm{a}}$ & $5.87^{\mathrm{a}}$ & $5.16^{\mathrm{a}}$ & $5.16^{\mathrm{a}}$ \\
\hline
\end{tabular}

Keterangan: Notasi huruf yang berbeda menunjukkan berbeda nyata pada $\alpha=0,05$.

Berdasarkan hasil uji mutu hedonik snack bar biji hanjeli dan kacang bogor didapatkan hasil yang tidak berbeda nyata pada semua perlakuan dengan parameter warna, aroma, rasa, dan tekstur pada taraf $0,05 \%$. Berdasarkan hasil penilaian panelis diperoleh nilai rata-rata mutu warna snack bar berkisar antara 5,73-6,07 ke arah warna cokelat mengkilap. Hal ini karena penggunaan binder berupa cokelat sehingga warna snack bar cenderung cokelat, sedangkan karakteristik mengkilap didapat dari cocoa butter yang dicampurkan pada binder yang memiliki warna mengkilap karena kandungan lemak di dalamnya. Nilai mutu aroma berkisar antara 5,87-6,24 ke arah aroma cokelat pekat sesuai dengan binder yang dipakai yaitu cokelat sehingga mendominasi aroma snack bar. Nilai mutu rasa berkisar antara 5,16-6,13 ke arah rasa manis. Rasa manis ini diperoleh dari cokelat yang digunakan dan nilai mutu tekstur berkisar antara 5,16-6,13 ke arah keras. Hal ini diduga karena karakteristik bahan baku yang digunakan yaitu biji hanjeli. Biji hanjeli memiliki struktur biji yang keras karena adanya matriks pati dan protein (Syahputri dan Agustin 2015).

\section{b. Uji Hedonik}

Analisis organoleptik juga dilakukan dengan metode uji hedonik untuk mengetahui tingkat kesukaan panelis terhadap snack bar biji hanjeli dan kacang bogor sehingga dapat dijadikan pertimbangan dalam menentukan formula terbaik (Meethal et al. 2017). Hasil uji 
hedonik snack bar biji hanjeli dan kacang bogor disajikan pada Tabel 3 .

Tabel 3. Hasil uji hedonik

\begin{tabular}{ccccc}
\hline Perlakuan & warna & aroma & rasa & tekstur \\
\hline $50: 50($ A1) & $6.43^{\mathrm{a}}$ & $6.13^{\mathrm{a}}$ & $6.26^{\mathrm{a}}$ & $6.39^{\mathrm{a}}$ \\
$60: 40$ (A2) & $6.60^{\mathrm{a}}$ & $6.14^{\mathrm{a}}$ & $6.13^{\mathrm{a}}$ & $5.98^{\mathrm{a}}$ \\
$70: 30$ (A3) & $6.32^{\mathrm{a}}$ & $6.01^{\mathrm{a}}$ & $6.48^{\mathrm{a}}$ & $6.19^{\mathrm{a}}$ \\
\hline
\end{tabular}

Keterangan: Notasi huruf yang berbeda menunjukkan berbeda nyata pada $\alpha=0,05$.

Berdasarkan hasil penilaian panelis diperoleh nilai rata - rata hedonik warna snack bar berkisar antara 6,01 - 6,63 ke arah disukai, aroma berkisar antara 5,82 - 6.43 kearah disukai, rasa berkisar antara 6.026,63 kearah disukai dan tekstur berkisar antara 5.75 - 6,65 kearah disukai. Hasil analisis sidik ragam (ANOVA) menunjukkan bahwa perbandingan konsentrasi beras hanjeli dan kacang bogor tidak berpengaruh nyata terhadap tingkat kesukaan panelis terhadap parameter warna, aroma, rasa dan tekstur produk snack bar ( $\mathrm{p}>0,05)$.

\section{Analisis Kandungan Energi}

Kandungan energi merupakan jumlah energi yang tersimpan dalam makanan yang telah ditentukan per unit volume atau massa, lemak menyimpan $9 \mathrm{kkal} /$ gram, karbohidrat dan protein masing - masing menyimpan 4 kkal/gram (Persagi 2010). Hasil energi/Kkal snack bar dapat dilihat pada Tabel 4 .

Tabel 4. Kandungan energi/Kkal

\begin{tabular}{cc}
$\begin{array}{l}\text { Perbandingan biji hanjeli } \\
\text { dan kacang bogor }(\%)\end{array}$ & Energi/Kkal \\
\hline $50: 50$ (A1) & $552,71^{\mathrm{a}}$ \\
$60: 40$ (A2) & $548,98^{\mathrm{b}}$ \\
$70: 30(\mathrm{~A} 3)$ & $523,30^{\mathrm{c}}$ \\
\hline
\end{tabular}

Keterangan: Notasi huruf yang berbeda menunjukkan berbeda nyata pada $\alpha=0,05$.

Hasil analisis sidik ragam menunjukkan bahwa perbandingan biji hanjeli dan kacang bogor berbeda nyata terhadap kandungan energi snack bar pada taraf $0,05 \%$. Semakin tinggi persentase kacang bogor pada formula menghasilkan nilai kalori yang semakin meningkat. Kadar lemak dan protein dapat berpengaruh terhadap peningkatan nilai energi snack bar (Tresnani et al. 2017). Sejalan dengan pernyataan Almatsier (2009) yang menyatakan bahwa kandungan karbohidrat, lemak, dan protein suatu bahan makanan dapat menentukan nilai energinya. Semakin tinggi kandungan protein, karbohidrat, dan lemak yang terkandung pada suatu produk maka semakin tinggi pula kalori yang diperoleh (Rinda et al. 2018). Kacang bogor diduga memberi kontribusi pada kandungan energi snack bar karena kacang bogor memiliki kandungan lemak dan protein yang cukup tinggi. Berdasarkan SNI, untuk golongan biskuit ditetapkan nilai energi minimum sebesar 400 kalori/100 gram. Snack bar biji hanjeli dan kacang bogor memiliki kandungan energi berkisar antara 523,30 - 552,71 Kkal/100gram bahan telah memenuhi standar.

\section{KESIMPULAN}

Snack bar dari biji hanjeli dan kacang bogor yang dihasilkan dalam penelitian ini memiliki karakteristik yaitu kadar air berkisar antara 2,13-2,63\%, kadar abu 2,27$2,60 \%$, kadar air protein 15,19-17,61\%, kadar lemak 28, 19-34,46\%, kadar karbohidrat 43,11-51,89\%. Perlakuan perbandingan biji hanjeli dan kacang bogor tidak berpengaruh nyata terhadap kadar air, akan tetapi berpengaruh nyata pada kadar abu, kadar protein, kadar lemak, dan kadar karbohidrat.

Karakteristik organoleptik snack bar biji hanjeli dan kacang bogor memiliki nilai parameter warna yang mengarah cokelat mengkilap, aroma cokelat pekat, rasa manis, dan tekstur yang keras. Ditinjau dari kandungan energi, snack bar yang dihasilkan memiliki kandungan energi 523,30 - 552,71 Kkal/100gram bahan telah memenuhi standar SNI biskuit.

Berdasarkan hasil uji kimia dan organoleptik serta perhitungan kandungan energi snack bar biji hanjeli dan kacang bogor, dapat disimpulkan bahwa produk ini berpotensi untuk dijadikan pangan bergizi dengan karakteristik yang disukai konsumen. 


\section{DAFTAR PUSTAKA}

Adhi RK dan Sholeh W. 2018. Pertumbuhan dan hasil kacang bogor (Vigna subterranean (L.) Verdc.) varietas local Lembang di Kalimantan Selatan. Ziraa'ah 43(2): 192-197).

Almatsier S. 2009. Prinsip Dasar Ilmu Gizi. PT Gramedia Pustaka Utama, Jakarta.

Amanto BS, Siswanti, Angga A. 2015. Kinetika pengeringan temu giring (Curcuma heyneana valeton \& van zijp) menggunakan cabinet dryer dengan perlakuan pendahuluan blanching. Jurnal Teknologi Hasil Pertanian 8(2): 107-114.

Andriani WORA, Ansharullah, Nur A. 2018. Karakteritik organoleptic dan nilai gizi snack bar berbasis tepung beras merah (Oryza nivara) dan tepung jagung (Zea mays L.) sebagai makanan selingan tinggi serat. Jurnal Sains dan Teknologi Pangan (JSTP) 3(6): 1448-1459.

[AOAC] Association of Official Analitical Chemist. 1995. Offcial Methods of Analysis of the Association of Official Analytical Chemist $16^{\text {th }}$. Arlington, Virginia: AOAC Inc.

Arwin, Tamrin, Abdu R. 2018. Kajian penilaian organoleptik dan nilai gizi snack bar berbasis tepung beras merah dan kacang merah (Phaseolus vulgaris L.) sebagai makanan selingan yang berserat tinggi. Jurnal Sains dan Teknologi Pangan 3(2):1152-1162.

Atmaka W, Nur HRP, Rohula U. 2013. Kajian fisikokimia dan sensori snack bar tempe bagi penderita autis. Jurnal Teknologi Hasil Pertanian 6(2): 119-126.

Ladamay NA, Yuwono SS. 2014. Pemanfaatan bahan lokal dalam pembuatan food bars (kajian rasio tapioca: tepung kacang hijau dan proporsi CMC). Jurnal Pangan dan Gizi 2(1):67-68.

Mazahib AM, Nuha MO, Salawa IS, and Babiker EE. 2013. Some nutritional attributes of bambara groundnut as influenced by domestic processing.
International Food Research Journal 20(3): 1165-1171.

Meethal SM, Narinder K, Jyoti S, Yogesh G. 2017. Effect of addition of Jackfruit seed flour on nutrimental, phytochemical and sensory properties of snack bar. Current Research in Nutrition and Food Science 5(2): 157-158.

Munir M, Muhammad N, Tahir MQ, Aqsa Q, Muhammad S, Falak Z, Ijaz U, Aneela Q Muthupandlan A. 2018. Addition of oat enhanced the physico-chemical, nutritional and sensory qualities of date fruit-based snack bars. Jurnal of Food and Nutrition Research 6(4): 271-276.

Nurmala T. 2010. Potensi dan prospek pengembangan hajeli (Cioa lacryma jobi L) sebagai pangan bergizi kaya lemak untuk mendukung diversifikasi pangan menuju ketahanan pangan mandiri. Jurnal Pertanian Universitas Padjajaran 20(1) 41-48.

Pahane MM, Tatsadjieu LN, Bernard C, Njintang YN. 2017. Production, nutritional, and biological value of Bambara Groundnut (Vigna subterranean) milk and yoghurt. Journal of Food Measurement and Characterization 11(4): 1613-1622.

[Persagi] Persatuan Ahli Gizi Indonesia. 2010. Tabel Komposisi Pangan Indonesia. PT Elex Media Komputindo, Jakarta.

Purwati NA, Dian H, Amalia R. 2015. Es krim free lactose berbahan dasar sari hanjeli sebagai alternative pengganti es krim susu bagi penderita lactose intolerance. Jurnal Aplikasi Teknologi Pangan 4(1): 36-41.

Qosim WA, dan Tati N. 2011. Eksplorasi, identifikasi dan analisis keragaman plasma nutfah tanaman Hanjeli (Coia lacryma jobi l.) sebagai sumber bahan pangan berlemak di Jawa Barat. Jurnal Pangan 20(4): 365-376.

Rahardjo L, Asrul B, Annis C. 2019. Pengaruh kombinasi kacang kedelai (Glycine max) 
dan kacang tunggak (Vigna unguiculate (L) walp.) yang diperkaya biji nangka (Artocarpus heterophyllus) terhadap daya terima dan kadar protein snack bar. Amerta Nutrition 3(1): 71-77.

Rinda, Ansharullah, Nur A. 2018. Pengaruh komposisi snack bar berbasis tepung tempe dan biji lamtoro (Leucaena leucocephala (Lam) de wit) terhadap penilaian organoleptik, proksimat, dan kontribusi kecukupan gizi. Jurnal Sains dan Teknologi Pangan (JSTP) 3(3): 13281340.

Sarifudin A, Riyanti E, Diki NS, Siti K. 2015. Pengaruh penambahan telur pada kanudngan proksimat, karaktersitik air bebas $\left(\mathrm{a}_{\mathrm{w}}\right)$ dan tekstural snack bar berbasis pisang (Musa paradisiaca). Agritech 35(1): 1-8.

Seismono dan Nikmatul H. 2011. Pengembangan Diversifikasi Pangan Pokok Lokal. Jurnal Pangan 20(3): 295314.

Siregar LNS, Noviar H, Rahmayuni. 2017. Pemanfaatan tepung kacang merah dan salak padang sidimpuan (Salacca sumatrana R.) dalam pembuatan snack bar. JOM Faperta 4(1): 1-14.

Syahputri DA, Agustin KW. 2015. Pengaruh fermentasi jali (Coix lacryma jobi-L) pada proses pembuatan tepung terhadap karakteristik fisik dan kimia cookies dan roti tawar. Jurnal Pangan dan Agroindustri 3(3): 984-995.

Tresnani RA, Maryam R, I Komang S. 2017. Subtitusi tepung komposit ubi jalar kuning (Ipomea batatas L.) dan kecambah kedelai (Glycine Max Merr) pada pembuatan snack barnforvita bagi balita gizi buruk fase rehabilitasi terhadap mutu kimia, nilai energi, mutu protein, mutu fisik, dan mutu organoleptik. Jurnal Ilmiah-Vidya 25(1): 86-95.

Utami P dan Sulistyani B. 2015. Potensi dan ketersediaan bahan pangan lokal sumber karbohidrat non biji di
Kabupaten Banyumas. Jurnal Dinamika Ekonomi dan Bisnis 12(2): 150-158.

Wibowo 0. 2013. Optimasi formulasi pembuatan snack bar kacang merah dan apel malang dengan menggunakan program linier. Artikel. Jurusan Teknologi Pangan Fakultas Teknik Universitas Pasundan, Bandung.

Wiryawan A. 2012. Analisis Proksimat. Universitas Brawijaya Press, Malang.

Yan MR, Andrew P, Gillian AW, John K, Elaine CR. 2017. Snack bar compotitions and their acute glycemic and satiety effects. Asia Pacific Journal Clinical Nutrition 26(4):624-629. 